\title{
Aortic elastic properties do not differ in patients with mitral valve prolapse
}

\section{Mitral kapak prolapsusu olan hastalarda farklılık göstermeyen aortanın elastik özellikleri}

\author{
Ahmet Karagöz ${ }^{1}$, Özgül Uçar Elalmış ${ }^{2}$, Havva Tuğba Gürsoy ${ }^{3}$, Deniz Şahin ${ }^{3}$, Mehmet İleri², Hülya \\ Çiçekçioğl u²
}

\section{${ }^{1}$ Department of Cardiology, Giresun University, Giresun, Turkey}

2Department of Cardiology, Ankara Numune Education and Research Hospital, Ankara, Turkey

${ }^{3}$ Department of Cardiology, Ankara Numune Education and Research Hospital, Ankara, Turkey

Corresponding author: Ahmet Karagöz, MD, Department of Cardiology, Giresun University, Giresun, Turkey

E-mail: drahmetkgz@hotmail.com

Received/Accepted: January 02, 2018 / May 07, 2019

Conflict of interest: There is not a conflict of interest.

\section{SUMMARY}

Objective: Mitral valve prolapse (MVP) is one of the most frequently seen cardiac disorders. The basic pathophysiologic mechanism is deterioration in the connective tissue leading to increased elasticity of mitral leaflets. Elasticity of the aorta, which is a well-established predictor of adverse cardiovascular outcomes, may also differ in these patients when an alteration in the connective tissue is taken into account. The aim of this study is to investigate the elastic properties of the aorta in patients with MVP.

Method: Thirty-seven patients with MVP and 38 healthy controls were evaluated in terms of aortic elastic properties using aortic strain, aortic stiffness index, and aortic distensibility.

Results: Median value for aortic strain was 0.07 (0.0338-0.231) in MVP group and $0.079(0.0345-0.28)$ in the control group $(\mathrm{p}=0.359)$. Aortic stiffness was calculated on the basis of aortic strain. The mean value for the stiffness index was $6.87 \pm 3.59$ and $6.21 \pm 2.83$ in the MVP and control groups, respectively $(\mathrm{p}=0.388)$. Distensibility of the aorta was quantified with a median value of 3286 (1229-12700) in patients with MVP and 3400 (1087$13790)$ in healthy subjects $(\mathrm{p}=0.346)$. Eventually, when the aortic elastic parameters were compared (aortic strain, stiffness index, and distensibility), no difference was found between MVP and control groups.

Conclusions: The elastic properties of the aorta do not differ in patients with MVP when compared to healthy individuals. It will not be accurate to predict long term cardiovascular outcomes based on elastic properties of the aorta in patients with MVP.

Keywords:Aortic stiffness, aortic strain, mitral valve prolapse

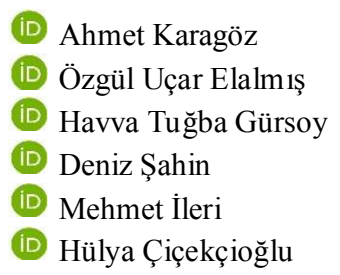

ORCID IDs of the authors: A.K. 0000-0002-3548-1276 Ö.U.E. 0000-0001-6932-8440 H.T.G. 0000-0002-3892-3930 D.Ş. 0000-0002-0236-3935 M.İ. 0000-0003-0941-7446 H.Ç. 0000-0001-6138-3699

\section{ÖZET}

Amaç: Mitral valv prolapsusu (MVP) en sık gözlenen kalp hastalıklarından bir tanesidir. Temel patofizyolojik mekanizma artmıș mitral yaprakçık elastisitesine neden olan bağ dokusundaki bozulmadır. Bağ dokusundaki bu değişiklik göz önünde bulundurulduğunda, iyi tanımlanmış bir advers kardiyovasküler olay ön gördürücüsü olan aort elastisitesinin de bu hastalarda değişiklik göstermesi beklenebilir. Bu çalışmanın amacı MVP olan hastalarda aortanın elastik özelliklerinin araştırılmasıdır.

Yöntem: Mitral valv prolapsusu olan 37 hasta ve 38 sağlıklı kontrol aortik strain, aortik katılık ve aortik genişleyebilirlik parametreleri kullanılarak aortanın elastik özellikleri açısından incelendi. 
Bulgular: MVP grubunda aortik strain için ortanca değer 0.07 (0.0338-0.231) iken kontrol grubunda 0.079 (0.0345$0.28)$ idi $(\mathrm{p}=0.359)$. Aortik katılık aortik strain esas alınarak hesaplandı. Katılık indeksi için ortalama değer MVP ve kontrol gruplarında sırası ile $6.87 \pm 3.59$ ve $6.21 \pm 2.83$ idi $(\mathrm{p}=0.388)$. Aortanın genişleyebilirliği ise MVP ve kontrol gruplarında sırası ile 3286 (1229-12700) ve 3400 (1087-13790) ortanca değerleri ile belirlendi $(\mathrm{p}=0.346)$. Sonuç olarak aortanın elastik özellikleri (aortik strain, katılık indeksi ve genişleyebilirlik) karşılaştırıldığında MVP ve kontrol grupları arasında fark bulunmadi.

Sonuç: MVP olan hastalarda aortanın elastik özellikleri sağlıklı bireylerle karşılaştırıldığında herhangi bir değişiklik göstermemektedir. MVP olan hastalarda aortanın elastik özelliklerine bakılarak uzun dönem kardiyovasküler sonuçlar öngörmek doğru olmayacaktır.

Anahtar sözcükler: Aortik sertlik, aortik strain, mitral kapak prolapsusu

\section{INTRODUCTION}

Mitral valve prolapse (MVP) is the most frequently seen valvular heart disease and defined as the displacement of mitral valve leaflet $>2 \mathrm{~mm}$ into the left atrium during systole. Leaflet thickening (in the classic form), chordal elongation, annular dilatation, and redundancy are other echocardiographic findings associated with MVP. Although mitral valve prolapse is one of the most common cardiac disorders, the data about the association between MVP and other cardiovascular or systemic diseases is limited.

The stiffness of the aorta affects aortic conduit function and causes an abnormal pressure pattern that leads to an increase in the afterload of the left ventricle. Consequently, increased aortic stiffness may induce left ventricular hypertrophy and may alter left ventricular diastolic and systolic function. ${ }^{1}$ It is well known that aortic stiffness is an independent predictor of all-cause and cardiovascular mortality in a different group of patients. ${ }^{2,3}$

The basic pathophysiologic mechanism in MVP is impairment of the connective tissue that results in increased elasticity of mitral leaflets. It can be speculated that increased elasticity observed inmitral valve prolapse could also be seen in the other tissues, and hence, the patients with MVP may have abnormal aortic elastic properties. However, the data about the elastic properties of the aorta in patients with MVP is limited. Several studies on this topic revealed conflicting results. ${ }^{4-}$ ${ }^{6}$ Herein, we also aimed to investigate the elastic properties of the aorta in patients with MVP.

\section{MATERIAL AND METHODS}

\section{General examination and measurements}

In the present study, 37 patients with MVP and 38 healthy controls were included. The subjects who had mitral leaflet thickening with echocardiographic evidence of $>2 \mathrm{~mm}$ systolic displacement of mitral valve leaflets into the left atrium (classic MVP) constituted the patient population. Exclusion criteria were the existence of severe mitral regurgitation, hypertension, diabetes mellitus, coronary artery disease, rheumatic heart disease, and end-stage renal disease. The patients under treatment for hyperlipidemia were also excluded. Clinical histories of all patients were recorded, and a general physical examination was carried out. Age, sex, weight, height, body mass index, blood pressure, and heart rate measurements of the patient and control groups were recorded. Blood pressure measurements were performed with mercuric sphygmomanometer under the guidance of ESH/ESC 2007 Arterial Hypertension Guideline simultaneously with the echocardiographic examination. The study was approved by the local ethical committee, and informed consent was obtained from all participants.

\section{Echocardiographic Assessment}

The echocardiographic assessment was performed with General Electric trademark (Vivid 7 Pro, Vingmed Ultrasound AS, Horton, Norway) echocardiography device by using 2.5-3.5 $\mathrm{MHz}$ transducer in the lateral decubitus position according to American Echocardiography Association guidelines with a simultaneously recorded electrocardiogram. Left atrium diameter and aortic diameter were measured on M-mode tracing at aortic sinus Valsalva level in the parasternal long axis view. Left ventricle endsystolic diameter, left ventricle end-diastolic diameter, posterior wall, and interventricular septum thickness were measured on the M-mode tracing at the papillary muscle level.

The diameter of the ascending aorta was measured from the same view on the M-mode tracing at a level of $3 \mathrm{~cm}$ above the aortic valve. The systolic aortic diameter (AOS) was measured at the maximal anterior motion of the aorta, whereas the diastolic aortic diameter (AOD) was measured at the peak of the QRS complex on the simultaneously recorded electrocardiogram. Consecutive five measurements were averaged. All echocardiographic evaluation was performed by an experienced physician aware of the study 
design. Following parameters of the aortic elasticity were calculated according to the following formulas:

Aortic strain $=[($ AOS - AOD $) / A O D]$,

Aortic stiffness $(\beta)$ index $=\ln$ (systolic blood pressure/diastolic blood pressure)/ aortic strain

Aortic distensibility $=2 \mathrm{x}$ aortic strain/pulse pressure

\section{Statistical Analyses}

Analyses were performed, using the MedCalc $\AA$ (Version 11.3.8.0) pocket program. The data were expressed as the mean \pm standard deviation (SD) and were tested for normal distribution using the Kolmogorov-Smirnov test. Comparisons between patients were made by using Student's independent t-test for normally distributed data or the Mann-Whitney $U$ test for non-normal distributed data. Difference between categorical variables was assessed using Chi-square or Fisher's exact test. The results were regarded as significant when $\mathrm{p}<0.05$.

\section{RESULTS}

Baseline characteristics of MVP and control groups are given in Table 1. The mean age was $35.4 \pm 11.9$ in patients with MVP while it was $36.2 \pm 8.2$ in the control group $(p=0.718)$. The study population consisted of 23 female and 14 male patients, and there were 21 female and 17 male subjects in the control group $(\mathrm{p}=0.709)$. Average systolic blood pressure was $124.3 \pm 17.5$ $\mathrm{mmHg}$ and $121.8 \pm 17.1 \mathrm{mmHg}$ in the MVP and control groups, respectively $(\mathrm{p}=0.546)$. Consequently, there was no significant difference between MVP and control groups by means of age, gender, systolic blood pressure. Diastolic blood pressure also did not differ between MVP and control groups and measured as $76.9 \pm 10.3$ $\mathrm{mmHg}$ and $75.2 \pm 11.7 \mathrm{mmHg}$, respectively $(\mathrm{p}=0.502)$. A similar number of individuals were a current smoker in MVP and control groups $(\mathrm{p}=0.709)$. There was also no statistically significant difference between two groups in terms of body mass index, fasting blood glucose, triglyceride, high-density lipoprotein (HDL), lowdensity lipoprotein (LDL) and total cholesterol levels ( $>>0.05)$.

Table 1: Baseline characteristics of MVP and control groups.

\begin{tabular}{llll}
\hline & MVP group $(\mathbf{n}=\mathbf{3 7})$ & Control group $(\mathbf{n}=\mathbf{3 8})$ & $\mathbf{p}$ \\
\hline Age (years) & $35.4 \pm 11.9$ & $36.2 \pm 8.2$ & 0.718 \\
Gender (n) & & & \\
$\quad$ Female & 23 & 21 & 0.709 \\
$\quad$ Male & 14 & 17 & 0.768 \\
Currently smoking (n) & 5 & 5 & 0.465 \\
FBG (mg/dl) & $93.8 \pm 9.9$ & $92.3 \pm 7.8$ & 0.651 \\
BMI & $22.7 \pm 3,1$ & $23,6 \pm 2,8$ & 0.123 \\
Total cholesterol (mg/dl) & $174.2 \pm 24.1$ & $182.1 \pm 19.4$ & 0.250 \\
LDL-C (mg/dl) & $107.1 \pm 25.6$ & $113.3 \pm 19.9$ & 0.213 \\
HDL-C (mg/dl) & $38.5 \pm 5.8$ & $40.1 \pm 4.9$ & 0.838 \\
TG (mg/dl) & $142.8 \pm 17.8$ & $143.6 \pm 16.8$ & 0.546 \\
SBP (mmHg) & $124.3 \pm 17.5$ & $121.8 \pm 17.1$ & 0.502 \\
DBP (mmHg) & $76.9 \pm 10.3$ & $75.2 \pm 11.7$ & 0.804 \\
PP (mmHg) & $47.3 \pm 11.6$ & $46.6 \pm 12.4$ & \\
\hline BMI Body & & & \\
\hline
\end{tabular}

BMI: Body mass index, DBP: Diastolic blood pressure, FBG: Fasting blood glucose, HDL-C: High-density lipoprotein cholesterol, LDL-C: Low-density lipoprotein cholesterol, PP: Pulse pressure, SBP: Systolic blood pressure, TG: Triglycerides 
Table 2: Echocardiographic measurements and aortic stiffness parameters.

\begin{tabular}{llll}
\hline & MVP $(\mathbf{n}=\mathbf{3 7})$ & Control $(\mathbf{n}=\mathbf{3 8})$ & $\mathbf{p}$ \\
\hline LA $(\mathbf{c m})$ & $3.52 \pm 0.51$ & $3.20 \pm 0.37$ & $\mathbf{0 . 0 3 8}$ \\
EDD $(\mathbf{c m})$ & $4.55 \pm 0.57$ & $4.22 \pm 0.34$ & 0.031 \\
ESD $(\mathbf{c m})$ & $2.62 \pm 0.39$ & $2.46 \pm 0.31$ & 0.168 \\
EF $(\boldsymbol{\%})$ & $72.1 \pm 4.59$ & $71.3 \pm 4.51$ & 0.549 \\
AOS $(\mathbf{c m})$ & $2.99 \pm 0.43$ & $3.05 \pm 0.38$ & 0.610 \\
AOD $(\mathbf{c m})$ & $2.76 \pm 0.44$ & $2.80 \pm 0.38$ & 0.686 \\
Strain * & $0.07(0.0338-0.231)$ & $0.079(0.0345-0.28)$ & 0.359 \\
Beta index & $6.87 \pm 3.59$ & $6.21 \pm 2.83$ & 0.388 \\
Distensibility $\left(\mathbf{1 0}^{\mathbf{6}}\right)^{*}$ & $3286(1229-12700)$ & $3400(1087-13790)$ & 0.346 \\
\hline
\end{tabular}

AOD: Diastolic aortic diameter, AOS: Systolic aortic diameter, EDD: End-diastolic diameter, EF: Left ventricular ejection fraction, ESD: End-systolic diameter, LA: Left atrium.

* Mann-Whitney U test was used.

Echocardiographic measurements and aortic elasticity parameters are demonstrated in Table 2. All subjects had normal left ventricular diameters and normal left ventricular ejection fraction $(p>0.05)$. Left atrial diameter was higher in patients with MVP when compared to controls $(p=0.038)$. Systolic aortic diameter at the maximal anterior motion of the aorta was measured to be $2.99 \pm 0.43 \mathrm{~cm}$ in the MVP group and $3.05 \pm 0.38$ $\mathrm{cm}$ in the control group ( $\mathrm{p}=0.610)$. The diastolic diameter of the aorta measured at the peak of the QRS complex was $2.76 \pm 0.44 \mathrm{~cm}$ and $2.80 \pm 0.38$ $\mathrm{cm}$ in the MVP and control group, respectively $(\mathrm{p}=0.686)$. In this study, our aim was to compare the elastic properties of the aorta between patients with MVP and healthy individuals. Median value for aortic strain was 0.07 (0.0338-0.231) in MVP group and $0.079(0.0345-0.28)$ in the control group ( $\mathrm{p}=0.359)$. Aortic stiffness was calculated on the basis of aortic strain. The mean value for the stiffness index was $6.87 \pm 3.59$ and $6.21 \pm$ 2.83 in the MVP and control groups, respectively $(\mathrm{p}=0.388)$. Distensibility of the aorta was quantified with a median value of 3286 (122912700) in patients with MVP and 3400 (1087$13790)$ in healthy subjects $(\mathrm{p}=0.346)$. Eventually, when the aortic elastic parameters were compared (aortic strain, stiffness index, and distensibility), no difference was found between MVP and control groups.

\section{DISCUSSION}

Our study results revealed that the patients with MVP had similar aortic elastic properties when compared to controls. The conflicting results in the previous trials gave rise to need for clarification of this topic via further studies since the identification of an increased aortic stiffness would put these patients at increased risk for future cardiovascular events or vice versa. However, no clear association was identified between aortic stiffness and existence of MVP in our study.

Aortic stiffness is well known to be an independent predictor of cardiovascular morbidity and mortality. ${ }^{7-9}$ Although the argument whether the aortic stiffness is only a marker of adverse cardiovascular outcomes or it is an accelerator of this process is still controversial; it has been hypothesized that abnormal arterial stiffness may cause an increase in the afterload and hence may impair left the ventricular diastolic function. This results in a decrease in left ventricular compliance through sub-endocardial ischemia, impaired myocardial relaxation, and interstitial fibrosis. ${ }^{10}$ Aortic stiffness, in addition to being a predictor for cardiovascular disorders, is an also indicator of future outcomes for some other diseases. The previous studies have already demonstrated that aortic stiffness is an independent predictor of stroke in hypertensive patients. ${ }^{11}$ Besides, independently of cardiovascular outcomes, aortic stiffness is a powerful predictor of mortality in chronic systemic diseases such as diabetes mellitus and chronic kidney disease. 12,13 Additionally, it has been revealed that aortic stiffness is increased in chronic rheumatismal disorders such as systemic sclerosis, systemic lupus erythematosus, and rheumatoid arthritis. ${ }^{14-16}$

The prevalence of the MVP is very high, especially in the young. ${ }^{17}$ The basic pathophysiologic mechanism is deterioration in the connective tissue leading to increased elasticity of mitral leaflets. Considering that the actual problem in MVP is in the connective tissue, we speculated that the elastic properties of the aorta, which have already been shown to be 
altered in various systemic rheumatismal diseases, may also be affected in patients with MVP. The number of studies on this topic is quite limited. Previously, Unlu M. et al. investigated elastic properties of the aorta in young male patients with classical and non-classical MVP and found that aortic strain and aortic distensibility were increased whereas the aortic stiffness index was decreased in the classical MVP group. ${ }^{4}$ Similarly, aortic stiffness index was found to be lower and aortic distensibility to be higher in patients with MVP in another study. ${ }^{5}$ Considering that the elasticity of the valvular tissue is increased in mitral valve prolapse, the existence of a concomitant reduction in the stiffness of aorta as revealed in these studies was an expected finding. Controversially, in the study that Kardesoglu E. et al. presented, it was unexpectedly found that the aortic stiffness index was increased whereas the aortic distensibility and strain index were decreased in patients with MVP. ${ }^{6}$ A possible correlation between the most common cardiac disorder, mitral valve prolapse, and aortic stiffness will be informative in terms of long term cardiovascular outcomes especially in the young. Nevertheless, these three studies revealed conflicting results. Therefore we designed another study evaluating aortic elastic properties in patients with MVP. We found no difference between the patients with MVP and healthy individuals by means of aortic elastic properties. Although the hypothesis that aortic elasticity can vary in patients with MVP is rational, previous studies have failed to demonstrate a clear correlation between elastic properties of the aorta and the mitral valve. Additionally, our study also revealed that there was no significant association between MVP and aortic elastic properties.

Some significant points about the strength and limitations of our study have also to be mentioned. The patients with diabetes, hyperlipidemia, coronary artery disease, or endstage renal disease were excluded from the study. Flow dynamics were also tried to be excluded by leaving hypertensive patients out; thus, the effect of confounding factors was aimed to be minimalized. Consequently, a potential variation in the elastic properties of the aorta would be attributed to the existence of MVP. Lack of a confirmation method like measurement of augmentation index (AI) and pulse wave velocity (PWV) can be considered as a limitation of the study. On the other hand, the method we used in this study is a well-established procedure for determining aortic elastic properties, and it has already been performed in the previous studies. ${ }^{18}$
Lack of the intra-observer variability analysis should also be mentioned as a limitation, although all measurements were performed in a blinded manner.

\section{CONCLUSION}

We found similar aortic elastic properties between MVP and control patients. The previous studies on this subject have not revealed a clear association. Stiffness of the aorta was found to be decreased in two of them, and another one demonstrated that aortic stiffness was increased in patients with MVP. Eventually, in the light of these findings, it will not be accurate to predict long term cardiovascular outcomes based on elastic properties of the aorta in patients with MVP.

\section{REFERENCES}

1. Zapolski T, Wysoki Ski A, Ksi Ek A, Jaroszy Ski A. Left atrial volume index and aortic stiffness index in adult hemodialysed patients-link between compliance and pressure mediated by endothelium dysfunction; a cross-sectional study. BMC Cardiovasc Disord 2012; 12: 100.

2. Laurent S, Boutouyrie P, Ama R, et al. Aortic stiffness is an independent predictor of all-cause and cardiovascular mortality in hypertensive patients. Hypertension 2001; 37: 1236-41.

3. Hsu SR, Su HM, Hsieh MC, et al. Risk factors of accelerated progression of peripheral artery disease in hemodialysis. Kaohsiung $\mathrm{J}$ Med Sci 2013; 29: 82-7.

4. Unlu M, Demirkol S, Aparci M, et al. Why aortic elasticity differs among classical and nonclassical mitral valve prolapsed? Clin Exp Hypertens 2014; 36: 148-52.

5. Yazici M, Ataoglu S, Makarc S, et al. The relationship between echocardiographic features of mitral valve and elastic properties of aortic wall and Beighton hypermobility score in patients with mitral valve prolapse. Jpn Heart J 2004; 45: 447 60.

6. Kardesoglu E, Ozmen N, Aparci M, et al. Abnormal elastic properties of the aorta in the mitral valve prolapse syndrome. Acta Cardiol 2007; 62: 151-5.

7. Boutouyrie P, Fliser D, Goldsmith D, et al. Assessment of arterial stiffness for clinical and epidemiological studies: methodological considerations for validation and entry into the European Renal and Cardiovascular Medicine registry. Nephrol Dial Transplant 2014; 29: 232-9. 
8. Liu CS, Li CI, Shih CM, et al. Arterial stiffness measured as pulse wave velocity is highly correlated with coronary atherosclerosis in asymptomatic patients. J Atheroscler Thromb 2011; 18: 652-8.

9. Vlachopoulos C, Aznaouridis K, Stefanadis C. Prediction of cardiovascular events and all-cause mortality with arterial stiffness: a systematic review and meta-analysis. J Am Coll Cardiol2010; 55: 1318-27.

10. Hu Y, Li L, Shen L, Gao H. The relationship between arterial wall stiffness and left ventricular dysfunction. Neth Heart J 2013; 21: 222-27.

11. Pereira T, Maldonado J, Pereira L, Conde J. Aortic stiffness is an independent predictor of stroke in hypertensive patients. Arq Bras Cardiol 2013; 100: 437-43.

12. Karras A, Haymann JP, Bozec E, et al. Large artery stiffening and remodeling are independently associated with all-cause mortality and cardiovascular events in chronic kidney disease. Hypertension2012; 60: 1451-7.

13. Mohty $D$, Pibarot $P$, Echahidi $N$, et al. Reduced systemic arterial compliance measured by routine Doppler echocardiography: a new and independent predictor of mortality in patients with type 2 diabetes mellitus. Atherosclerosis2012; 225: 353-8.
14.Uçar Elalmış O, Ciçekçioğlu H, Karagöz A, Ozbalkan Aşlar Z, Karaaslan Y. Evaluation of aortic elastic properties in patients with systemic sclerosis. Turk Kardiyol Dern Ars 2014; 42: 63542.

15. Santos MJ, Carmona-Fernandes $D$, Canhão $H$, et al. Early vascular alterations in SLE and RA patients--a step towards understanding the associated cardiovascular risk. PLoS One 2012; 7: e44668.

16. Balcı H, Demirkök SS, Yıldız M, et al. The relationship between inflammatory markers and arteriel distensibility in patients with sarcoidosis. Balkan Med J 2010; 27: 44-50

17. Schmeisser A, Flachskampf FA. [Mitral valve prolapse]. Z Kardiol 2000; 89: 349-53.

18. Moyssakis I, Gialafos E, Vassiliou V, et al. Aortic stiffness in systemic sclerosis is increased independently of the extent of skin involvement. Rheumatology 2005; 44: 251-4. 